\title{
Impact of Market Ratios on the Stock Prices: Evidence from Jordan
}

\author{
Sufian Radwan Al-Manaseer ${ }^{1}$ \\ ${ }^{1}$ Business Economic Department, Business Faculty, Tafila Technical University, Jordan \\ Correspondence: Dr. Sufian Radwan Al-Manaseer, Business Economic Department, Business Faculty, Tafila \\ Technical University, P. O. Box 179, Tafila 66110, Jordan.
}

Received: February 26, 2020

Accepted: March 18, 2020

Online Published: March 20, 2020

doi:10.5539/ibr.v13n4p92

URL: https://doi.org/10.5539/ibr.v13n4p92

\begin{abstract}
This study aims to investigate the impact of market ratios on the stock prices of Jordanian industrial companies listed on the Amman Stock Exchange for the period 2009-2018. The sample comprises 45 chosen from 56 industrial companies. Fixed effect regression analysis applied by using an e-views program. The study found an impact of the combined market ratios on the stock prices of Jordanian industrial companies. Also, the study found no impact of the dividend payout, the dividend yield, and the price-earnings ratios on the stock prices, whereas the earnings per share ratio impact the stock prices of Jordanian industrial companies listed on the Amman Stock Exchange.
\end{abstract}

Keywords: dividend payout, dividend yield, earnings per share, industrial companies, price-earning, stock prices

\section{Introduction}

The main goal of stock investors is to make profits. To achieve this, they need information about the company, which is of fundamental importance in forecasting stock prices; therefore, financial ratios are among the most important tools and methods used to analyze and interpret financial data. Razuk (2001) defined financial ratios as mathematical relationships among related numbers got from the financial statements. Karami and Talaeei (2013) used the relationship between one or more variables to show the strengths and weaknesses of the company and make sound investment decisions.

Moradi (2006), must determine the factors that affect stock prices because investment in stocks considered one of the most preferred investments in which it can achieve a higher return when compared with other investments, where the characteristics of companies affect 50\% of stock prices (Drummen and Zimmermann, 1992).

The stock prices are important indicators for investors to determine whether or not to invest in a particular company. Because stock prices are unstable, thus investors seek to determine the most influential variables on stock prices. (Uddin et al., 2013).

This study aims to determine the impact of market ratios on the stock prices, because of limited studies regarding the impact of market ratios on the stock prices of the Jordanian industrial companies, this study aims to explain such an impact to serve as a reference for those who are interested to invest in stocks of Jordanian industrial companies.

The following questions are answered in this study:

1. Do market ratios affect the stock prices?

Several follow-up questions arise from this question:

1.1 Does the dividend payout ratio affect the stock prices?

1.2 Does the dividend yield ratio affect the stock prices?

1.3 Does the earning per share ratio affect the stock prices?

1.4 Does the price-earnings ratio affect the stock prices?

The paper planned as follows. Section 1 introduction. Section 2 theoretical framework and previous studies. Section 3 methodology, hypotheses, population and sample, and the mathematical model of the study. Section 4 discusses the statistical analysis, hypothesis testing, and results. Section 5 recommendations and cites the 
limitations of the study.

\section{Theoretical Framework and Previous Studies}

Financial analysis is mainly concerned with the collection, classification, and measurement of financial information, especially those related to financial statements published by the company. An analysis of financial statements is a tool for interpreting these statements and for knowing the relationship between the numbers included in them (Ross et al., 2010).

The importance of financial analysis stems from it considered a way to know the company's financial and administrative capabilities, as it provides information that helps in assessing the value of the company and assessing the performance of the company, an important means of internal control, and an effective tool that helps in knowing the strengths and weaknesses of the company (Ross et al., 2010).

There are many entities interested in financial statements and analysis, such as management; Company investors such as shareholders, bondholders, banks and financial institutions; Company dealers such as suppliers and employees; Other analysts such as the government, competitors, and intermediaries (Ross et al., 2010).

Financial ratios are among the most common tools and convenient way to summarize a large amount of accounting and financial information to compare corporate performance, but there is no specific list that includes all ratios approved for analysis. Also characterized by the fact that they enable the analyst to overcome the problem of size, which arises when comparing the accounting numbers and financial indicators of companies for which there is a large variation in size (Ross et al., 2010).

Ross et al. (2010) divided financial ratios into five main types:

1. Liquidity ratios, that concerned with the company's ability to pay off its short-term debt.

2. Activity ratios, that concerned with measuring the company's liquidity and efficiency in managing its receivables and its stocks.

3. Debt ratios called financial leverage ratios, that concerned with measuring the company's ability to pay its debts and interest on its due date, in addition to the extent to which the company used the funds of others to fund its assets.

4. Profitability ratios, that concerned with analyzing the company's ability to achieve profits from the basic operations that the company was originally established to perform.

5. Market ratios, that concerned with knowing the impact of the company's performance on the expected returns from investing in the company's shares. Market ratios can be divided into:

5.1 Dividend payout ratio: It measures the dividends attributable to ordinary shares. This percentage may be low if the company has high and continuous growth rates, a decrease in this percentage may show that the company maintains the largest portion of the profits to finance growth internally, as shareholders prefer a low distribution rate if the company can achieve a rate of return on undistributed profits Higher than the rate at which the shareholder investor may realize these profits if they distributed, and he invested them.

5.2 Dividend yield: it's the expected dividend as a percentage of the market share price.

5.3 Earning per share: It expresses the number of profits that the ordinary shareholder will receive after deducting the share of preference shares from net profit after interest and taxes. Where the higher the percentage, the more this indicates an increase in the efficiency of the company because an increase will positively affect the share price in the market, while other factors remain constant.

5.4 Price-earnings ratio: this ratio measures the price the investor pays for each dinar of the current period's profits, as this ratio reflects how the market estimates both the company's expected future profits and the risks associated with these profits.

Stock prices are important for investors because of their effect on the movement of financial markets, and reflect the value of the company in the market. Also, the shareholder wealth and the value of the company increase as the stock prices increase, and vice versa. However, a remarkable increase will reduce the ability of investors to buy.

The relationship between financial ratios and stock prices is important; nevertheless, several theories have regarded the relationship between economic variables and stock prices. Fama (1970) proposed in the efficient market theory that stock prices have important information for stock indexes, whereas Ross (1976) in the arbitrage theory confirmed the effect of micro- and macroeconomic variables on stock prices. Both theories showed a change in stock prices due to the combination of factors represented in several financial ratios. 


\subsection{Previous Studies}

Numerous studies have been conducted on the relationship between financial ratios and stock returns in different countries and for different sectors, but studies examining the effect of market ratios on stock prices are limited.

Dobija and Klimczak (2010) studied the evolution of the information environment surrounding the companies listed on the Warsaw Stock Exchange in Poland from 1997 to 2008. The study found a positive relationship between financial ratios and stock prices.

Dzikevičius and Šaranda (2011) discussed the ability of financial ratios to forecast the stock prices of five companies listed in the Lithuanian Stock Exchange from 2007 to 2010. Among the 20 financial ratios studied, a positive effect is found on the relationship between ownership and profitability ratios. Also, the debt ratio has a negative impact on stock prices, while return on assets and return on equity have a negative and positive impact on stock prices, respectively.

Dadrasmoghadam and Akbari (2015) investigated the relationship among financial ratios in the stock prices of agriculture-related firms accepted on the stock exchange for Iran from 1999 to 2009. A significant impact is found on the relationship among the current ratio, debt ratio, and return on assets, and return on equity has a positive impact on the stock prices.

Prazak and Stavarek (2017) discussed the effect of financial ratios on the stock prices of energy firms listed on the Prague Stock Exchange and the Warsaw Stock Exchange from 2006 to 2015. They found a positive impact of financial leverage ratios and a negative impact of liquidity ratios on the stock prices in both countries.

Ligocka and Stavarek (2019) studied 20 food companies listed on the various European Stock Exchanges from 2005 to 2015. The sample comprises four Austrian, 10 Polish, and six Swiss companies. Positive and negative correlations are found between financial ratios and stock prices.

As for local studies, Kabajeh et al. (2012) studied the relationship among the ratios of the ROA, ROE, ROI, and the stock prices of Jordanian insurance companies from 2002 to 2007. The study found a positive relationship between the combined ratios and stock prices, a weak positive relationship between the return on investment, and the return on assets with stock prices, while there's no relationship between return on equity with stock prices.

Al-Eitan and Al Oleemat (2015) discussed the causal relationship between the performance of financial market indicators and financial ratios from 2010 to 2014. The financial ratios, that is, price to book value, price to earnings, and dividends to yield ratios, have a causal effect on the performance of financial market indicators.

Allozi and Obeidat (2016) investigated the relationship between profitability and leverage ratios with the stock returns in Jordanian manufacturing companies from 2001 to 2011. Gross profit margin, return on equity, return on assets, and earning per share have an impact on stock returns. By contrast, the debt, current, and debt to equity ratios do not affect stock returns.

Al Kubaisi et al. (2017) discussed the predictive role of the fundamental financial ratios for the stock returns of Jordanian commercial banks from 2006 to 2015 . They found that the fundamental financial ratios did not play a role in predicting stock returns over time.

What distinguishes this study from previous studies? First, this study examines the impact of market ratios on stock prices, whereas other studies focus on the impact of different financial ratios on stock returns. Second, this study chooses four market ratios, whereas other studies choose specific ratios of liquidity, solvency, and profitability. Third, this study takes all Jordanian industrial companies, whereas other studies choose different sectors or several industrial companies. Last, this study gathers data from 2009 to 2018, a period that hasn't studied before.

\section{Methodology}

\subsection{Study Hypotheses}

Main hypothesis:

$\mathrm{H}_{0}$ : Market ratios have no impact on the stock prices.

Sub-hypotheses:

$\mathrm{H}_{01}$ : The dividend payout ratio has no impact on the stock prices.

$\mathrm{H}_{02}$ : The dividend yield ratio has no impact on the stock prices.

$\mathrm{H}_{03}$ : The earning per share ratio has no impact on the stock prices. 
$\mathrm{H}_{04}$ : The price-earnings ratio has no impact on the stock prices.

\subsection{Population and Sample}

The study population comprises all the Jordanian industrial companies listed in the Amman Stock Exchange of 56, while the study sample comprises 45 industrial companies whose stocks listed on the Amman Stock Exchange for the period 2009-2018. Eleven industrial companies excluded because of limited financial data for the entire study period. Apart from this, the study sample fulfilled the following conditions:

1- Availability of all data to test the variables.

2- The company was not subject to mergers.

3- The fiscal year ends on December 31 of every year.

4- The financial reports of the study sample are available for the period under examination and analysis.

5- The company's listing on the Amman Stock Exchange continues for the period under examination and analysis.

We got all data from the annual financial reports of industrial companies listed on the Amman Stock Exchange.

\subsection{Mathematical Model}

In line with the study variables, the mathematical equations are:

$$
\begin{aligned}
& \mathrm{SP}_{\mathrm{it}}=\mathrm{a}_{0}+\mathrm{a}_{1} \mathrm{DPR}_{\mathrm{it}}+\mathrm{a}_{2} \mathrm{DY}_{\mathrm{it}}+\mathrm{a}_{3} \mathrm{EPS}_{\mathrm{it}}+\mathrm{a}_{4} \mathrm{PER}_{\mathrm{it}}+\mathrm{e}_{\mathrm{it}}, \\
& \mathrm{SP}_{\mathrm{it}}=\mathrm{a}_{0}+\mathrm{a}_{1} \mathrm{DPR}_{\mathrm{it}}+\mathrm{e}_{\mathrm{it}}, \\
& \mathrm{SP}_{\mathrm{it}}=\mathrm{a}_{0}+\mathrm{a}_{1} \mathrm{DY}_{\mathrm{it}}+\mathrm{e}_{\mathrm{it}}, \\
& \mathrm{SP}_{\mathrm{it}}=\mathrm{a}_{0}+\mathrm{a}_{1} \mathrm{EPS}_{\mathrm{it}}+\mathrm{e}_{\mathrm{it}}, \\
& \mathrm{SP}_{\mathrm{it}}=\mathrm{a}_{0}+\mathrm{a}_{1} \mathrm{PER}_{\mathrm{it}}+\mathrm{e}_{\mathrm{it}},
\end{aligned}
$$

\begin{tabular}{|c|c|}
\hline Variables & Description \\
\hline \multicolumn{2}{|l|}{ Dependent variable } \\
\hline Stock price & closed price for the fiscal year $i$ \\
\hline \multicolumn{2}{|l|}{ Independent variables } \\
\hline Dividend payout ratio & dividend per share/earnings per share \\
\hline Dividend yield ratio & cash dividends /market capitalization \\
\hline Earnings per share & net income/number of subscribed shares \\
\hline Price-earnings ratio & market capitalization /net income pertains to shareholders \\
\hline
\end{tabular}

Where DPR is the dividend payout ratio, DY is the dividend yield ratio, EPS is the earnings per share ratio, PER is the price-earnings ratio, and SP is the stock price.

\subsubsection{Mathematical Equation Variables}

Table 1. Measurement of mathematical equation variables

The researcher prepared the table based on several previous studies.

\section{Statistical Analysis}

\subsection{Descriptive Analysis}

Table 2. Descriptive statistics of the study variables

\begin{tabular}{|l|c|c|c|c|c|}
\hline & DPR & DY & EPS & PER & SP \\
\hline Mean & 0.509 & 0.0347 & 0.197 & 47.268 & 2.330 \\
\hline Std. Dev. & 3.258 & 0.283 & 0.351 & 261.795 & 4.821 \\
\hline
\end{tabular}

Table 2 shows that the price-earnings ratio has the highest mean of 47.628 and the highest standard deviation of 261.795, which shows a high rate in the price-earnings ratio of Jordanian industrial companies.

The dividend yield ratio has the lowest mean of 0.0347 and the lowest value of standard deviation of 0.283 , which shows a low rate in the dividends in Jordanian industrial companies. 


\subsection{Correlation Analysis}

Pearson correlation matrix estimated to specify the multicollinearity problem.

Table 3. Pearson correlation matrix among the study variables

\begin{tabular}{|c|c|c|c|c|c|}
\hline $\begin{array}{c}\text { Independent } \\
\text { variables }\end{array}$ & SP & DPR & DY & EPS & PER \\
\hline SP & 1 & & & & \\
\hline DPR & 0.020119 & 1 & & & \\
\hline DY & 0.006948 & 0.025880 & 1 & & \\
\hline EPS & 0.809808 & -0.019702 & -0.000815 & 1 & \\
\hline PER & 0.024685 & 0.267585 & -0.012649 & -0.076521 & 1 \\
\hline
\end{tabular}

Table 3 shows that the earning per share ratio has the lowest and highest Pearson correlation coefficient. The lowest value was 0.000815 with the dividend yield ratio, whereas the highest value was 0.809808 with the stock price. Hence, there's no multicollinearity problem between the study variables.

We also note that stock prices have a weak positive correlation with the dividend payout, dividend yield, and price-earnings ratios, and a high positive correlation with the earnings per share ratio.

\subsection{Hypothesis Testing}

If the probability $<0.05$, then reject the null-hypothesis and accept the alternative one. Also, the $\mathrm{R}^{2}$ show the ability to explain the change in the dependent variables by the independent variables.

\subsubsection{Main Hypothesis Testing}

Table 4. Results of the multiple linear regression of Eq. (1)

\begin{tabular}{|l|r|r|r|}
\hline Independent variables & \multicolumn{2}{|c|}{ Coefficient } & t-Statistic \\
\hline C & 1.244360 & 10.17303 & 0.0000 \\
\hline DPR & -0.016387 & -0.553576 & 0.5802 \\
\hline DY & 0.241079 & 0.744459 & 0.4570 \\
\hline EPS & 5.292923 & 12.68608 & 0.0000 \\
\hline PER & 0.000916 & 2.457448 & 0.0144 \\
\hline Notes: implies significance at 5\%; $\mathrm{R}^{2}=0.8742 ;$ Adj. $\mathrm{R}^{2}=0.8559 ;$ F-stat. $=47.8018 ;$ D.W. $=0.995 ;$ F-prob. $=0.000$ \\
\hline
\end{tabular}

Table 4 shows the following:

(1) The correlation coefficient among the stock prices and the dividend payout ratio is -0.016387 , and the probability is 0.5802 . This result indicates that the dividend payout ratio has a weak negative impact on stock prices.

(2) The correlation coefficient among the stock prices and the dividend yield ratio is 0.241079 , and the probability is 0.4570 . This result indicates that the dividend yield ratio has a weak positive impact on stock prices.

(3) The correlation coefficient among the stock prices and the earning per share ratio is 5.292923, and the probability is 0.000 . This result indicates that the earning per share ratio has a high positive impact on stock prices.

(4) The correlation coefficient among the stock prices and the price-earnings ratio is 0.000916 , and the probability is 0.0144 . This result indicates that the price-earnings ratio has a weak positive effect on stock prices.

(5) The $\mathrm{R}^{2}$ is 0.8742 , indicating the ability of the market ratios to explain the changes in the stock prices by $87.42 \%$.

The Durbin-Watson value is 0.995 , approving that no multicollinearity problem exists.

The probability of combined market ratios 0.000 , so we reject the main null-hypothesis and accepted the 
alternative one, which that the combined market ratios have an impact on the stock prices of Jordanian industrial companies.

\subsubsection{Sub-hypothesis Testing}

Table 5. Results of the simple linear regression of independent variables based on Eqs. (2) - (5)

\begin{tabular}{|c|l|l|l|l|l|}
\hline $\begin{array}{c}\text { Independent } \\
\text { variables }\end{array}$ & \multicolumn{1}{|c|}{ Coefficients } & \multicolumn{1}{|c|}{$\mathbf{R}^{\mathbf{2}}$} & \multicolumn{1}{|c|}{ D.W. } & \multicolumn{1}{|c|}{ t-Stat. } & Prob. \\
\hline DPR & -0.006392 & 0.821736 & 0.482017 & -0.189317 & 0.8499 \\
\hline DY & 0.205050 & 0.821849 & 0.481807 & 0.534368 & 0.5934 \\
\hline EPS & 5.211486 & 0.872114 & 0.955877 & 12.47610 & 0.0000 \\
\hline PER & 0.000492 & 0.822328 & 0.493364 & 1.162723 & 0.2456 \\
\hline Notes: implies significance 5\%
\end{tabular}

As shown in Table 5, the correlation coefficient among the stock prices and the dividend payout ratio is -0.006392 , which indicates that the dividend payout ratio has a weak negative impact on the stock prices. The $\mathrm{R}^{2}$ is 0.821736 , indicating the ability of the dividend payout ratios to explain the changes in the stock prices by $82.1736 \%$. The Durbin-Watson value is 0.482017 , approving that no multicollinearity problem exists. The value of probability was 0.8499 , indicating that the dividend payout ratio has no impact on the stock prices in the Jordanian industrial companies listed on the Amman Stock Exchange. Hence, we rejected the alternative first sub-hypothesis and accepted the first null sub-hypothesis.

The correlation coefficient between the stock prices and the dividend yield ratio is 0.205050 , which indicates that the dividend yield ratio has a weak positive impact on the stock prices. The $\mathrm{R}^{2}$ is 0.821849 , indicating the ability of the dividend yield ratio to explain the changes in the stock prices by $82.1849 \%$. The Durbin-Watson value is 0.481807 , approving that no multicollinearity problem exists. The value of probability is 0.5934 , indicating that the dividend yield ratio has no impact on stock prices in the Jordanian industrial companies listed on the Amman Stock Exchange. Hence, we rejected the alternative second sub-hypothesis and accepted the second null sub-hypothesis.

The correlation coefficient between the stock prices and the earnings per share ratio is 5.211486, which indicates that the earnings per share ratio has a high positive impact on the stock prices. The $\mathrm{R}^{2}$ is 0.872114 , indicating the ability of the earnings per share ratio to explain the changes in the stock prices by $87.2114 \%$. The DurbinWatson value is 0.955877 , approving that no multicollinearity problem exists. The value of probability is 0.000 , indicating that the earning per share ratio has an impact on stock prices in the Jordanian industrial companies listed on the Amman Stock Exchange. Hence, we rejected the third null sub-hypothesis and accepted the alternative one.

The correlation coefficient between the stock prices and the price-earnings ratio is 0.000492 , which indicates that the price-earnings ratio has a weak positive impact on the stock prices. The $\mathrm{R}^{2}$ is 0.822328 , indicating the ability of the price-earnings ratio to explain the changes in the stock prices by $82.2328 \%$. The Durbin-Watson value is 0.493364 , approving that no multicollinearity problem exists. The value of probability is 0.2456 , indicating that the price-earnings ratio has no impact on stock prices in the Jordanian industrial companies listed on the Amman Stock Exchange. Hence, we rejected the alternative forth sub-hypothesis and accepted the fourth null sub-hypothesis.

\section{Conclusion}

This study aims to investigate the impact of market ratios on the stock prices of Jordanian industrial companies listed on the Amman Stock Exchange from 2009 to 2018. The sample comprises 45 chosen from 56 industrial companies. Fixed effect regression analysis applied by using an e-views program.

The study found an impact of the combined market ratios on the stock prices of Jordanian industrial companies. Also, the study found no impact of the dividend payout, the dividend yield, and the price-earnings ratios on the stock prices, whereas the earnings per share ratio impact the stock prices of Jordanian industrial companies listed on the Amman Stock Exchange.

Based on the results, we recommend the following: 
1. Investors should consider these market ratios in choosing stocks and making rational decisions.

2. Future research may add other variables, such as liquidity ratios, Activity ratios, Debt ratios, Profitability ratios, GDP growth, inflation.

This study limited to Jordanian industrial companies, thus unlikely to generalizing the results to other companies. The study period is 2009-2018, so it cannot adopt the result for a different period. Finally, studying a few market ratios, not all financial ratios.

\section{References}

Al Kubaisi, A. S., Afaneh, O., \& Al Assuli, A. (2017). Analysis of the Role of Fundamental Financial Ratios in Predicting the Stock Returns for Commercial Banks Listed on Amman Stock Exchange. Research Journal of Finance and Accounting, 8(8), 1-16. Retrieved from https://www.iiste.org/Journals/index.php/RJFA/article/view/36769

Al-Eitan, G., \& Al Oleemat, N. (2015). The Causality Relationship between Financial Market Indexes and Financial Ratios: Evidence from Amman Stock Exchange. International Journal of Academic Research in Accounting, Finance and Management Sciences, 5(2), 23-31. https://doi.org/10.6007/IJARAFMS/v5-i2/1559

Allozi, N., \& Obeidat, G. (2016). The Relationship between the Stock Return and Financial Indicators (Profitability, Leverage): An Empirical Study on Manufacturing Companies Listed in Amman Stock Exchange". Journal of Social Sciences (COES\&RJ-JSS), 5(3), 408-424. https://doi.org/10.25255/jss.2016.5.3.408.424

Dadrasmoghadam, A., \& Akbari, S. (2015). Relationship between financial ratios in the stock prices of agriculture-related companies accepted on the stock exchange for Iran. Research Journal of Fisheries and Hydrobiology, 10(9), 586-591. Retrieved from http://www.aensiweb.com/old/jasa/rjfh/2015/May/586-591.pdf

Dobija, D., \& Klimcza, K. M. (2010). Development of Accounting in Poland: Market Efficiency and the Value Relevance of Reported Earnings. International Journal of Accounting, 45(3), 356-374. https://doi.org/10.1016/j.intacc.2010.06.010

Drummen, M., \& Zimmermann, H. (1992). The structure of European stock returns. Financial Analysts Journal, 48(4), 15-26. https://doi.org/10.2469/faj.v48.n4.15

Dzikevicius, A., \& Šaranda, S. (2011). Can financial ratios help to forecast stock prices? Journal of Security and Sustainability Issues, 1(2), 147-157. https://doi.org/10.9770/jssi.2011.1.2(7)

Fama, E. (1970). Efficient capital markets: A review of theory and empirical work. Journal of Finance, 25, 383-417. Retrieved from https://www.jstor.org/stable/2325486

Kabajeh, M., Al Nu'aimat, S., \& Dahmash, F. (2012). The Relationship between the ROA, ROE and ROI ratios with Jordanian Insurance Public Companies Market Share Prices. International Journal of Humanities and Social Science, 2(11), 115-120. Retrieved from https://www.ijhssnet.com/journal/index/1041

Karami, G. R., \& Talaeei, L. (2013). Predictability of stock returns using financial ratios in the companies listed in Tehran Stock Exchange. International Research Journal of Applied and Basic Sciences, 5(3), 360-372. Retrieved from https://pdfs.semanticscholar.org/772e/3fc3ab0cfab33221d694707fd9add78a7c0a.pdf

Ligocka, M., \& Stavarek, D. (2019). The Relationship Between Financial Ratios and the Stock Prices of Selected European Food Companies Listed on Stock Exchanges. Acta Universitatis Agriculturae et Silviculturae Mendelianae Brunensis, 67(1), 299-307. https://doi.org/10.11118/actaun201967010299

Moradi, A. (2006). The relationship between financial ratios and stock returns in the Tehran Stock Exchange. A Master's thesis accounting, Tarbiat Modarres University.

Prazak, T., \& Stavarek, D. (2017). The effect of financial ratios on the stock price development. Working Paper in Interdisciplinary Economics and Business Research no. 43. Silesian University in Opava, School of Business Administration in Karviná. Retrieved from http://www.iivopf.cz/images/Working_papers/WPIEBRS2017/WPIEBRS_43_Prazak_Stavarek.pdf

Razuk, F. G. (2001). An assessment of financial ratios as predictors of casino stocks' behavior (Master's Thesis) Graduate College University of Nevada, Las Vegas. https://doi.org/10.25669/cr4y-q3xf

Ross, S. A. (1976). The arbitrage theory of capital asset pricing. Journal of Economic Theory, 13(3), 341-360. 
https://doi.org/10.1016/0022-0531(76)90046-6

Ross, S., Westerfield, R., \& Jordan, B. (2010). Fundamental of Corporate Finance (9th ed.). McGraw-Hill, New York.

Uddin, R., Rahman, Z. \& Hossain, R. (2013). Determinants of stock prices in financial sector companies in Bangladesh- a study on Dhaka stock exchange (DSE). Interdisciplinary Journal of Contemporary Research in Business, 5(3), 471-480. Retrieved from https://journal-archieves34.webs.com/471-480.pdf

\section{Copyrights}

Copyright for this article is retained by the author(s), with first publication rights granted to the journal.

This is an open-access article distributed under the terms and conditions of the Creative Commons Attribution license (http://creativecommons.org/licenses/by/4.0/). 